\title{
FORMING SOFT SKILLS OF UNIVERSITY STUDENTS BY MEANS OF ACADEMIC ROLE-PLAYING GAMES AT FOREIGN LANGUAGE CLASSES
}

\author{
Ida K. Tsalikova, Svetlana V. Pakhotina \\ Tyumen State University, Ishim, Russian Federation
}

\begin{abstract}
The article contains theoretical grounds and experimental verification of using academic roleplaying games at classes of Foreign Language in order to form soft skills of students, majoring in nonphilological subjects. The purpose of the article is to analyze the effectiveness of using this form of work at university classes for the formation of soft skills of students and to monitor the correlation between these skills.

The methodological basis of the study was the communicative and competence-based approaches in teaching foreign languages. Research methods include questioning, observation, expert assessment and testing. The obtained data were subjected to statistical analysis using Kolmogorov-Smirnov's test, Pearson's $\chi^{2}$ test and Spearman's rank correlation coefficient.

Academic role-playing games have shown their effectiveness as a means offorming soft skills of students, majoring in non-philological subjects, in case of following such fundamental principles as: using the language as an integral system but not as a set of grammatical and lexical phenomena; using language as a means of communication, and, consequently, a teacher's making educational materials and tasks, focused on the content of communication, but not on the formal characteristics; creating practice-oriented situations in the classroom that train social skills, but not just subject knowledge and skills. The article presents a description of training materials, tasks, methods and forms of work for the formation of students' soft skills.

Key words: soft skills, forming soft skills, group work, academic role-playing game, majoring in nonphilological subjects, English language training.
\end{abstract}

\section{Introduction}

The changes, taking place in the education system at present, put new educational guidelines and requirements for professional activity; it puts all the disciplines studied at the university not only to serve the professional development of a student, but also his personal development. Social intelligence (not the cognitive one) is evaluated by specialists (sociologists, anthropologists, psychologists, marketing specialists (Herzig et al, 2017)) as a decisive factor for personal success, successful employment and career growth, which is reflected in educational standards.

Considering the tendency of university students' training to practical orientation, the experience of solving practical situations that train social skills and abilities, and not just subject ones, becomes particularly relevant. It is impossible to learn it, simply by acquiring knowledge, without specially-created learning situations, tasks that form the skills and abilities, generally defined as soft skills.

In different countries of the world recommendations on the development of soft skills in higher education system appeared in the 1950s of the last century. The need to take the development of soft skills in the process of acquiring subject knowledge and professional competencies into account is indicated by the results of meaningful researches, carried out all over the world. For example, in a study conducted by Harvard University, together with the Carnegie Foundation and the Stanford Research Institute, it is indicated that success in a professional sphere depends on the level of soft skills for $75-85 \%$ and only for $15-25 \%$ it is defined by professional subject or so-called "hard" skills (Robles, 2012). This is confirmed by the study of Sisson and Adams (2013).

The report of the Organization for Economic Cooperation and Development on the results of a three-year study, named "Skills for Social Progress. The Power of Social and Emotional Skills" (OECD Skills Studies, Skills for Social Progress) also states the fundamental importance (compared 
to academic performance) of a student's emotional and communicative qualities for his future life and professional success.

In recent years, universities have increasingly attracted employers to the educational process and work with students. This is a consequence of the fact that when studying the opinion of employers about the level of training of graduates, it is said that even young employees, who know their subject matter, are not ready to solve practical professional tasks (Robles, 2012; Andrews and Higson, 2010; Gale et al., 2017; Balcar et al., 2018; Bartel, 2018; Kaburise, 2016; Callier et al., 2014; Dorozyński et al., 2016).

In the world, the process of monitoring the views of employers and their participation in the development of educational standards and programs began much earlier than in Russia. Thus, in the United States in 2006, a similar study demonstrated that, according to employers, the least developed graduates' soft skills are precisely the skills of interaction and creative approach to the performance of labor functions (Are They Really Ready to Work?...). The need to improve teamwork skills and its direct connection with the quality of work, for example, the quality of medical services provided, is also indicated by a later study (Al-Araidah et al, 2018). In 2010 in the United Kingdom of Great Britain and Northern Ireland, Slovenia, Romania and Austria the results of some studies, which analyzed the quality of the graduates' labor market and their ability to meet the needs of employers, were published (Andrews \& Higson, 2010). Similar studies were carried out by Sisson and Adams (2013); Mardis et al. (2018); Gale et al. (2017); Balcar et al. (2018); Pang et al. (2018). In the study by Cobb et al. (2015) they share the experience of creating an association of graduates who, during the first year after graduation from the university, realized at their first workplace that there were no soft skills formed during their studies, despite good substantive training. Mohamed et al. (2017) talk about the graduates' experience in grading soft skills not even by employers, but by consumers of their services.

Some researchers attribute the problem of high unemployment rate among recent university graduates to their lack of well-developed communication skills (Valentin et al., 2015; Kaburise, 2016).

A number of scientific researches confirm the opinion of employers about the need for soft skills of both technical specialists (Pezer, 2015; Mardis et al., 2018; Fernández-Sanz et al., 2017; Chasidim et al., 2018; Brooks et al., 2018; Chowdary, 2014) and representatives of creative professions (Sisson \& Adams, 2013; Gale et al., 2017). But still the problem of forming soft skills among students, majoring in Science and non-philological subjects, seems to be more relevant. For example, Chamorro-Premuzic et al. (2010), after analyzing the results of three studies of universities in the United Kingdom, found that soft skills are more developed in students, majoring in Humanities, than in those who study social and natural sciences. Scientists have established a direct relationship between the level of soft skills development and educational achievements of students and insist that $20 \%$ of the disciplines of their curricular are not "technical", but devoted, for example, to learning a language, the development of communication skills, management skills, projects, personal development, etc (Hillmer, 2007).

In foreign studies, the possibility of forming soft skills in parallel with the process of subject learning has been actively discussed for a long time. For example, in February 2014, a report on such parallel activity, organized in three states - Arizona, Wisconsin and California, was released in the USA (Best Practices in Soft Skills Assessment).

When getting higher education, a student hopes to be competitive at the labor market, but not just to master an educational program. Gaines and Mohammed (2013) write about the equal importance for a graduate of both subject knowledge and the ability to apply them (which, in fact, is a complex of soft skills). That is why, forming educational paradigm of the 21 st century, researchers note that the experience of creating separate training courses for forming soft skills outside the 
subject context was not successful and suggest that the best way to do this - is to develop them in the process of studying academic subjects (Barseghian, 2011; Callier et al., 2014).

Educational institutions in different countries solve the problem of forming soft skills through academic subjects in many ways, but scientists speak of the need to change educational programs in order to focus them on the formation of soft skills (Vo et al., 2017; Callier et al., 2014; Mardis et al., 2018; Pang et al., 2018; Brooks et al., 2018; Ritter et al., 2018).

This can be a set of skills strictly defined by an institution, which is fixed by its curriculum, or the development of certain skills can be "assigned" to specific subject disciplines. Moreover, in a number of educational institutions attempts are being made to put the principle of group work into the basis of their educational programs (Larmer \& Mergendoller, 2010). Today, universities in different countries use the experience of each other, trying to ensure the development of students' soft skills during their subject studies. In one of the universities of China, 29 second-year students were trained on a specially-organized program for the development of soft skills. The program was taken from the work experience of the University of Australia (Yan et al., 2018).

Studies in the field of soft skills are still carried out. The subject of the study is the diagnosis and evaluation of soft skills (Balcar et al., 2018; Mohamed et al., 2017; Brooks et al., 2018; Devedzic et al., 2018); the use of various approaches, methods and techniques, for example, interdisciplinary design work (Vogler et al., 2018), group work (Al-Araidah et al., 2018; Chasidim et al., 2018; Brooks et al., 2018; Yehia \& Gunn, 2018; Espey, 2018; Kusumoto, 2018); the development of some certain skills, for example, collaboration skills (Kaburise, 2016; Al-Araidah et al., 2018), critical thinking (Espey, 2018), etc.

Group work as a means of forming soft skills have exceptional potential (Al-Araidah et al., 2018; Chasidim et al., 2018; Brooks et al., 2018; Yehia \& Gunn, 2018; Espey, 2018; Kusumoto, 2018); it derives from the very definition of the concept of soft skills - a complex of social and communication skills that ensure effective communication and teamwork. The terms of "hard skills" and "soft skills" appeared as an analogy to computer terms "hardware" and "software" and were later extrapolated to the social sphere from economics and business (Cambridge Dictionary, Collins Dictionary).

Group work makes it possible to form and develop the skills of teamwork, communication and critical thinking (Al-Araidah et al., 2018; Chasidim et al., 2018; Brooks et al, 2018; Yehia \& Gunn, 2018; Espey, 2018; Kusumoto, 2018) in the most natural way.

The idea of using language disciplines as a means of developing soft skills is widely used (Bartel, 2018; Kusumoto, 2018).

Foreign Language as an academic subject (even if it is not a subject of the major professional curriculum) has tremendous potential for solving this problem, since it is a social subject in its essence. The principal goal of mastering this discipline is not to master individual speech units, but to make language a means of communication.

In reality, at practical university classes on Foreign Language, there is a predominance of the traditional frontal form of work in the "student-teacher" mode. In other countries, where these processes began much earlier than in Russia, they increasingly turn to the principles of learning in collaboration, moving away from simple relaying of knowledge (Tagg, 2003; Yehia \& Gunn, 2018; Espey, 2018; Kusumoto, 2018; Dalton-Puffer \& Nikula, 2014). Passive forms of learning (the transfer of ready-made knowledge, their repetition and memorization) imply the primary role of a teacher not only in transmitting knowledge, but also in creating curricula and defining assessment criteria. The principle of active learning allows students to study and be responsible for their education; they have a higher level of intellectual development and satisfaction with studying at a university. A lot of research is devoted to studying the experience of integrating Foreign Language as a subject in a higher education institution into developing critical thinking skills, which is called 
Content and Language Integrated Learning (Kusumoto, 2018; Dalton-Puffer \& Nikula, 2014), based on the same principle of active learning.

Although the problem of forming soft skills in general and individual skills in particular and the use of various methods, techniques and tools among various categories of students is the subject to a sufficiently large number of foreign studies, it should be recognized that in Russia the problem of training graduates with these skills (especially by means of Foreign Language classes for students, majoring in non-philological subjects) has not been solved yet, which significantly complicates the successful career growth of our graduates.

In order to solve this problem, a complex of academic role-playing games was developed, aimed at forming soft skills in the process of learning a foreign language.

\section{Research Methodology}

The main approaches to the teaching of foreign languages in Russia are communicative and competence-based ones.

In the communicative approach, the language is a means of communication, so real situations are recreated in the training process, authentic materials are used and there is no division of the language into its formal components.

Competence-based approach implies the ability to solve communicative tasks; readiness and ability of mutual understanding and interaction; independence and practical orientation as well as tolerance.

The conceptual principles of these approaches provide excellent opportunities for the formation of a number of "soft" skills, including skills of interaction, creative thinking and communication.

The experiment was carried out at classes on Foreign Language (English) with the first and second-year students (1-3 semesters), majoring in non-philological sciences in a teachers training university. The start of the experiment is the 1st semester of the 2015-2016 academic year (102 students in the experimental groups) and the 1st semester of the 2016-2017 academic year (127 students in the experimental groups). In total, 229 teachers-to-be, majoring in Biology and Chemistry; History and Geography; Mathematics and Physics; Primary and Pre-School Education participated in the experiment. The total duration of the experiment is 3 years.

The experiment was conducted in two stages, as since 2016 the curricula of these educational programs has been changed towards a significant increase in the total number of classes of Foreign Language (practical training time increased by $52 \%$, and the time, allotted for independent students' work was prolonged by $8 \%$ ).

The pedagogical experiment was conducted using questionnaires, including observation, expert assessment, testing and analysis of educational and cognitive activities of students, majoring in non-philological subjects.

The students' level of the skills was evaluated with the use of the method of an expert assessment, on a scale from 0 to 2 , where 2 - the highest level of development of relevant quality or skills, 1 - average level, 0 - low one (the skill is not formed). The total score was determined by the arithmetic mean of the sum of the points awarded by experts for each of the skills separately. The high professional and pedagogical competence of all the selected experts allowed for using the arithmetic mean of their estimates without additional coefficients.

Initially, at each stage, in order to determine the level of skills being studied, the ascertaining diagnostic measures were carried out in accordance with the criteria and indicators and using the diagnostic methods given in Tables 1,2 .

Table 1. Soft skills, indicators and methods for assessing students' soft skills. 


\begin{tabular}{|c|c|c|}
\hline Collaboration & Communication & Critical Thinking \\
\hline $\begin{array}{l}\text { - agree upon the goals } \\
\text { and standards for joint work, } \\
\text { assign roles; } \\
\text { - discuss the difficulties } \\
\text { encountered in the interaction } \\
\text { and ways to avoid them; } \\
\text { - quickly adapt to } \\
\text { accepted rules; } \\
\text { - } \quad \text { organize team } \\
\text { interaction; } \\
\text { - } \quad \text { structure the work of } \\
\text { the group; } \\
\text { - } \quad \text { activate passive } \\
\text { participants; } \\
\text { - use a comfortable (but } \\
\text { constructive) role for yourself } \\
\text { and fulfill it consciously; } \\
\text { - } \quad \text { show your ambitions } \\
\text { constructively; } \\
\text { - } \quad \text { offer several solutions } \\
\text { to the problem; } \\
\text { - not show emotional } \\
\text { reactions to the individual } \\
\text { characteristics of other team } \\
\text { members; } \\
\text { - evaluate your impact } \\
\text { on other team members; } \\
\text { - pay more attention to } \\
\text { your own participation in } \\
\text { group discussions (statements, } \\
\text { presentation of your own } \\
\text { point of view, reaction to the } \\
\text { opinions of others, etc.) in } \\
\text { which you are not a leader. }\end{array}$ & $\begin{array}{l}\text { - understand the purpose } \\
\text { of communication (both your } \\
\text { own, and of the interlocutor); } \\
\text { - treat the interlocutor } \\
\text { attentively and with interest; } \\
\text { - structure information } \\
\text { from problem to solution; } \\
\text { - regulate your non- } \\
\text { verbal manifestations during } \\
\text { communication, understand } \\
\text { non-verbal feedback; } \\
\text { - change the } \\
\text { communication strategy } \\
\text { depending on the information } \\
\text { received; } \\
\text { - } \quad \text { adapt the style of } \\
\text { communication to the level of } \\
\text { the interlocutor; } \\
\text { - keep eye contact with } \\
\text { the interlocutor; } \\
\text { - } \quad \text { to interest the } \\
\text { interlocutors and engage them } \\
\text { in the discussion; } \\
\text { • } \quad \text { build a conversation on } \\
\text { the principle of dialogue: ask } \\
\text { questions, listen to the } \\
\text { interlocutor, comment; } \\
\text { - apply active listening } \\
\text { techniques; } \\
\text { - give clear answers to } \\
\text { the questions of the } \\
\text { interlocutors. }\end{array}$ & $\begin{array}{l}\text { - understand and } \\
\text { express the meaning of } \\
\text { different situations, data, } \\
\text { events, judgments; } \\
\text { - understand conceived } \\
\text { and factual logical } \\
\text { connections between } \\
\text { statements of questions; } \\
\text { - evaluate the } \\
\text { plausibility of statements and } \\
\text { judgments; } \\
\text { - identify and relate the } \\
\text { elements necessary to extract } \\
\text { sound conclusions; formulate } \\
\text { assumptions and hypotheses; } \\
\text { • examine relevant } \\
\text { information and identify the } \\
\text { consequences arising from } \\
\text { data, statements, factual } \\
\text { material, judgments; } \\
\text { formulate the results of } \\
\text { reasoning; explain this } \\
\text { reasoning in obvious terms } \\
\text { on which the results are } \\
\text { based; } \\
\text { • present reasoning } \\
\text { with convincing arguments; } \\
\text { - consciously control } \\
\text { your own mental operations. }\end{array}$ \\
\hline \multicolumn{3}{|c|}{ Diagnostic methods } \\
\hline
\end{tabular}

Table 2. Levels of soft skills formation.

\begin{tabular}{|c|c|c|}
\hline Low & Medium & High \\
\hline $\begin{array}{l}\text { A student does not have a } \\
\text { skill, does not understand its } \\
\text { importance, does not try to } \\
\text { develop and use it. }\end{array}$ & $\begin{array}{l}\text { A student is in the process of } \\
\text { mastering a skill, understands } \\
\text { its importance, but does not } \\
\text { always effectively apply it in }\end{array}$ & $\begin{array}{l}\text { A student has fully mastered a } \\
\text { skill and always effectively } \\
\text { applies it in a standard training } \\
\text { situations. }\end{array}$ \\
\hline
\end{tabular}


As for the evaluation criteria, the recommendations, set forth in the works by Diaz et al. (2010) and Fiore et al. (2017), were taken as the basic ones: the participants of the game were evaluated for each of the components (subject knowledge and soft skills, demonstrated during the game) separately. For the experiment presented here, only the data on the evaluation of the level of soft skills are given.

After the first academic role-playing game was carried out, students in their mini-groups answered a few questions. The questionnaire was compiled using the SGA method - The Small Group Analysis (Small Group Analysis). The same questionnaire was used at the final stage of the experiment.

Dear student!

Please use this form as a constructive way to provide feedback to your teacher about using role-playing games as a method of teaching and developing your skills. Plan your comments as carefully as possible so that your teacher can determine what steps to take to make this type of work more effective for you. Your answers to this questionnaire must be returned to the teacher and will be used only by him (her). At the end of the semester, you will be asked to answer similar questions so that the teacher can understand whether the game as a form of work has become effective as a means of learning and as a means of developing your soft skills.

Thanks for your help.

Course

1. What was, in your opinion, the goal of the academic role-playing game?

2. Did you understand exactly what was required of you during the preparation process or during the game itself? If not, explain why?

3. What stage of the game has become for you

- $\quad$ the easiest to perform

- $\quad$ the most difficult to perform

- $\quad$ the most useful for mastering the subject

- $\quad$ the most useful for your personal development.

4. How can this form of work help you in

- $\quad$ mastering the academic subject

- $\quad$ personal development.

5. What would you like to change in the organisation and conduct of the academic roleplaying game?

6. What advice would you give to a teacher in organising and conducting role-playing games?

The technology of an academic role-playing game includes the following components: a target one, a theoretical and a methodological ones, an informative one, an organizational and a result-obtaining ones. The organizational unit of an academic role-playing game is as follows:

Stage 1 (preparatory)

A teacher, developing the game scenario, thinks out the supporting schemes for each of the participants with the necessary lexical minimum as a support and offers possible options for the distribution of roles. Students participate in the distribution of roles (this trains their ability to agree on goals and norms of teamwork; to adapt quickly to the accepted rules; to organize teamwork; to structure the work of the group and to activate low-active participants) and suggest topics for discussion, anticipate possible questions and answers to them.

Stage 2 (game playing)

Inside a group, students alternately have to assume the function of a leader when performing a specific task - this is also crucial for developing communication and interaction skills. Students 
present their own judgments on given topics, answer questions from the audience and participants of other teams (practice of understanding the goals of communication - both of their own and those of an interlocutor; of being attentive and interested in an interlocutor; of structuring information from problem to solution; of regulating their nonverbal manifestations; changing the communication strategy depending on the information received; adapting the communication style to the level of an interlocutor; building a conversation based on the principle of a dialogue: to ask questions, to listen to the other person, to comment, to use active listening techniques and so on). At this stage, students need habits that are part of the critical thinking skill: to formulate the results of reasoning; to explain this reasoning in obvious terms on which the results are based; to present reasoning with convincing arguments; to consciously control their mental operations.

Stage 3 (analysis)

It allows you to get instant feedback from different experts - classmates and a teacher (who usually takes on the role of a coach, but can delegate it to someone from the students) - they can be asked to monitor the manifestation of different skills, and further on to discuss the feedback received and to take notes of the most important issues. Here it is necessary to determine the winners of the debate; "viewers" participate in this process - they observe the discussion, can ask questions and participate in the discussion itself and evaluate the work of the teams according to the criteria they know in advance (this trains the skills of critical thinking - to understand the intended and actual logical connections between statements of questions; to assess the plausibility of statements, judgments; to identify and relate the elements necessary for drawing sound conclusions; to form assumptions and hypotheses; to study relevant information and to identify the consequences arising from the data.

Let us take, for example, the scenario of the game, organized as the debate "For and against using IT-technologies in teaching".

1. Preparation:

- $\quad$ Choose the Chairman of your debate.

- $\quad$ Divide into two teams.

Team A

A teacher actively using IT in his work

An inexperienced teacher who is a digital native (uses computer since his earliest childhood)

An IT specialist

A school head teacher

- $\quad$ Follow the role cards

\section{Chairman:}

You declare the debate open and closed.

You give the floor to the speakers, the audience, keep order and time the presentations.

You are also responsible for making quick decisions about any problem that arises during the debate.

You summarize the decision of the debate at the end of the session.

Teams:

Work out a list of arguments to support your idea.

You may use the following ideas: Computers as entertainment at school; Educational values of IT; Mind-expanding role of IT; Exposure for violent scenes, improper contents of the Internet; 
Copying violent behavior; Violation of copy rights; Becoming computer-addicted; Distracting from other important activities; Integral part of progress.

Make a list of arguments the opposing team might use and work out counter-arguments.

Choose the team leader. He/She will be first and last to speak in your team.

Distribute the tasks between team members.

Choose a secretary who will take notes of the Study the Language Support box.

Audience:

Work out a list of questions for Teams A and B.

Choose the Chairman.

Study the evaluation card below.

Word List

\section{a Chairman:}

Team Members and Audience:

Ladies and gentlemen, could I have your Yes, but do you really think...

attention, please.

Let me open / close the discussion...

I give the floor to...

May I ask you to...

Unfortunately, your time is up.

Does the audience have any questions?

I invite the audience to vote for the decision.
Yes, but at it like this...

I agree, but on the other hand...

That's true, but if you look at it from the point of view...

I'm all for it...

I disapprove of...

I approve of...

Evaluation card for the audience is given in Table 3.

Table 3. Evaluation card for the audience.

\begin{tabular}{|c|c|c|c|c|c|}
\hline Evaluation card for the audience & $\begin{array}{c}\text { Very } \\
\text { poor - } 1\end{array}$ & 2 & 3 & 4 & $\begin{array}{c}\text { Excellent } \\
-5 \\
\end{array}$ \\
\hline How convincing is the argument? & & & & & \\
\hline How convincing is the counter-argument? & & & & & \\
\hline $\begin{array}{l}\text { How prepared was the team to answer the } \\
\text { questions? }\end{array}$ & & & & & \\
\hline
\end{tabular}

2. Activity

- $\quad$ Follow up the debate procedure 


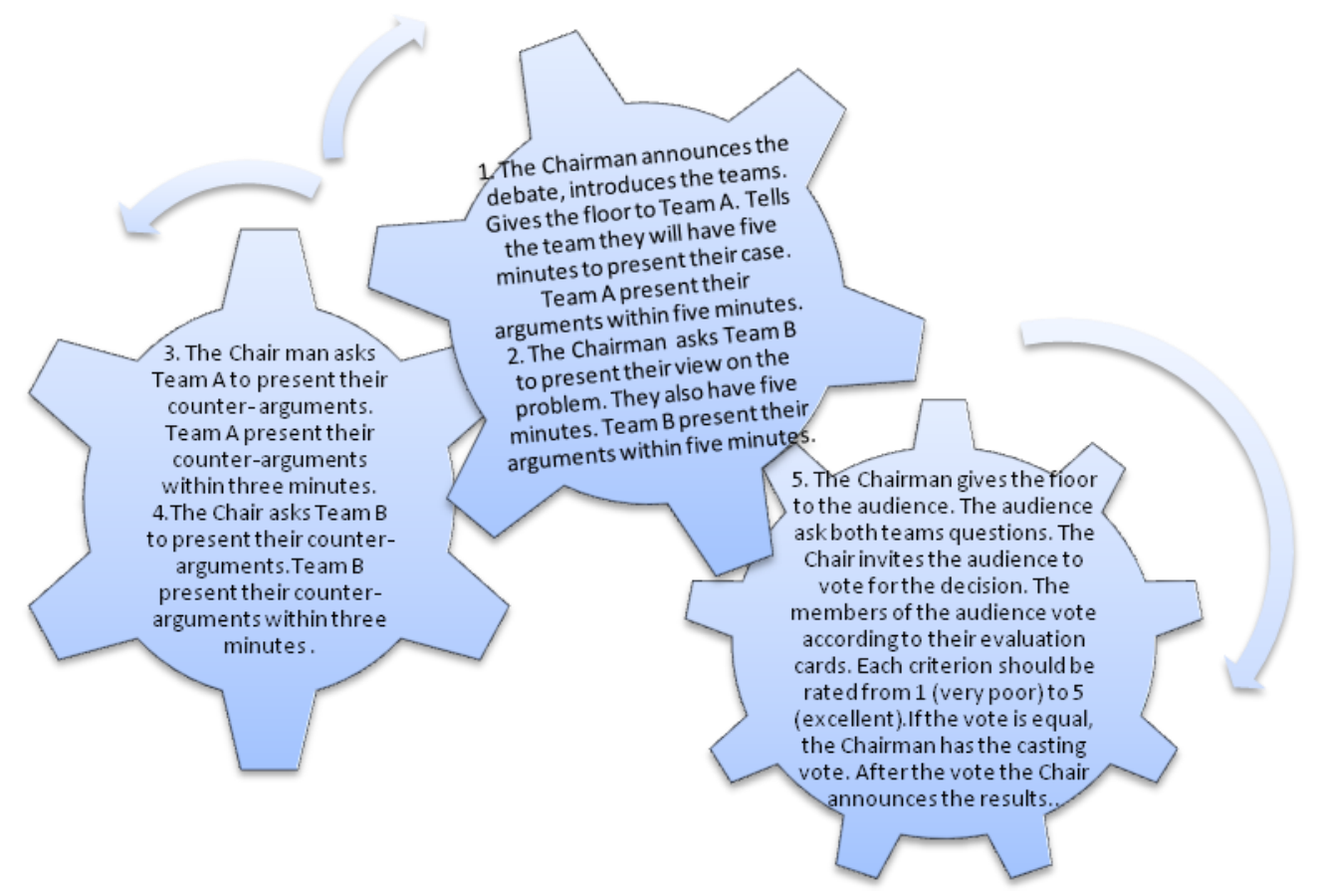

Figure 1: Debate procedure.

3. Follow-up

- $\quad$ Discuss the debate

Why did the debate have this result?

Which team was stronger? Why? Refer to your evaluation cards.

What was the role of the audience? Did it play its role?

Table 4. Academic role-playing game.

\begin{tabular}{|c|c|}
\hline Goal-defining unit & $\begin{array}{l}\text { Goal: to form soft skills of students } \\
\text { by means of academic role-playing games }\end{array}$ \\
\hline \multirow{2}{*}{$\begin{array}{l}\text { Theories and } \\
\text { methods defining } \\
\text { unit }\end{array}$} & Approaches \\
\hline & Competence approach \\
\hline $\begin{array}{l}\text { Content defining } \\
\text { unit }\end{array}$ & $\begin{array}{l}\text { Conceptual grounds } \\
\text { use of language as a whole, rather than a set of grammatical and } \\
\text { phenomena; } \\
\text { mastering knowledge and soft skills in the process of independent } \\
\text { activity; } \\
\text { an equivalent concentration of tasks on the language content and } \\
\text { orientation; } \\
\text { prevalence of group work; } \\
\text { language as a means of communication. }\end{array}$ \\
\hline \multirow[t]{4}{*}{ Arrangement unit } & Stages of an academic role-playing game \\
\hline & Stage 3 \\
\hline & Preparation \\
\hline & $\begin{array}{l}\text { Training methods: methods of stimulating and motivating learning and } \\
\text { cognitive activity, methods of organizing and implementing learning and } \\
\text { cognitive activity, methods of control and self-control }\end{array}$ \\
\hline
\end{tabular}




\begin{tabular}{|c|c|c|c|}
\hline & \multicolumn{3}{|c|}{ Training tools: visual, technical } \\
\hline & \multicolumn{3}{|c|}{ Forms of study: group work } \\
\hline \multirow{2}{*}{$\begin{array}{l}\text { Effectiveness } \\
\text { defining unit }\end{array}$} & \multicolumn{3}{|c|}{ Results } \\
\hline & Subject & Subdisciplinary & Personal \\
\hline
\end{tabular}

The experiment was carried out with the approval of Tyumen State University. We have also received informed documented consent of all educational experiment participants.

\section{Research Results}

An analysis of general results of the ascertaining diagnostic measures showed that, initially, for most participants of the experiment, the soft skills being studied were formed at a moderate or low level; the development of the components of each of the skills is not uniform; the ones, developed at the middle level are: the ability to agree on goals and distribute roles, build a conversation on the basis of a dialogue, understand and express the meaning of judgments; the ones, developed insufficiently are the following: the ability to activate passive partners, change the communication strategy depending on the information, identify the consequences of the data obtained, the ability of convincing argumentation. The results of the incoming diagnostics of both stages of the experiment (2015-2016 and 2016-2017 academic years) are comparable, which indicates a stable level of soft skills development of high school graduates (Table 5).

In the 2015-2016 and 2016-2017 academic years, control and experimental groups were set up at some non-philological educational programs (mentioned above) to learn English. For three semesters in experimental groups, the study of each unit of the subject program was completed with academic role-playing games.

In experimental groups, the game has always followed the study of a particular topical unit, becoming a way of summing it up, checking a certain unit of subject knowledge and practicing soft skills.

At the end of the experiment, the final diagnostics was carried out; its results are presented in Table 5 and Figure 2.

Table 5. The resulting levels of the soft skills being researched.

\begin{tabular}{|c|c|c|c|c|c|c|c|c|c|c|c|c|c|}
\hline \multirow[t]{2}{*}{ Stage } & \multirow[t]{2}{*}{ Level } & \multicolumn{4}{|c|}{ Collaboration, \% } & \multicolumn{4}{|c|}{ Communication, \% } & \multicolumn{4}{|c|}{ Critical Thinking, \% } \\
\hline & & $\begin{array}{l}\mathrm{Ad} \\
\mathrm{Cg}\end{array}$ & $\mathrm{Cg}$ & $\begin{array}{l}\mathrm{Ad} \\
\mathrm{Eg}\end{array}$ & $\mathrm{Eg}$ & $\begin{array}{l}\mathrm{Ad} \\
\mathrm{Cg}\end{array}$ & $\mathrm{Cg}$ & $\begin{array}{l}\mathrm{Ad} \\
\mathrm{Eg}\end{array}$ & $\mathrm{Eg}$ & $\begin{array}{l}\mathrm{Ad} \\
\mathrm{Cg}\end{array}$ & $\mathrm{Cg}$ & $\begin{array}{l}\text { Ad } \\
\text { Eg }\end{array}$ & $\mathrm{Eg}$ \\
\hline \multirow{4}{*}{ Stage 1} & & & & & & & & & & & & & \\
\hline & high & 12 & 6 & 4 & 11 & 16 & 20 & 11 & 27 & 10 & 12 & 11 & 11 \\
\hline & average & 28 & 64 & 31 & 79 & 48 & 60 & 54 & 69 & 30 & 48 & 29 & 58 \\
\hline & low & 70 & 30 & 65 & 10 & 36 & 20 & 35 & 4 & 60 & 40 & 60 & 31 \\
\hline \multirow[t]{3}{*}{ Stage 2} & high & 3 & 5 & 3 & 8 & 9 & 16 & 16 & 22 & 8 & 11 & 8 & 19 \\
\hline & average & 50 & 70 & 52 & 84 & 69 & 67 & 62 & 75 & 51 & 61 & 56 & 64 \\
\hline & low & 47 & 25 & 45 & 8 & 22 & 17 & 22 & 3 & 41 & 28 & 36 & 17 \\
\hline
\end{tabular}

Note: Ad $\mathrm{Cg}$ - ascertaining diagnostics in the control group, $\mathrm{Cg}-$ final diagnostics in the control group, Ad $\mathrm{Eg}$ - ascertaining diagnostics in the experimental group, $\mathrm{Eg}$ - final diagnostics in the experimental group. 


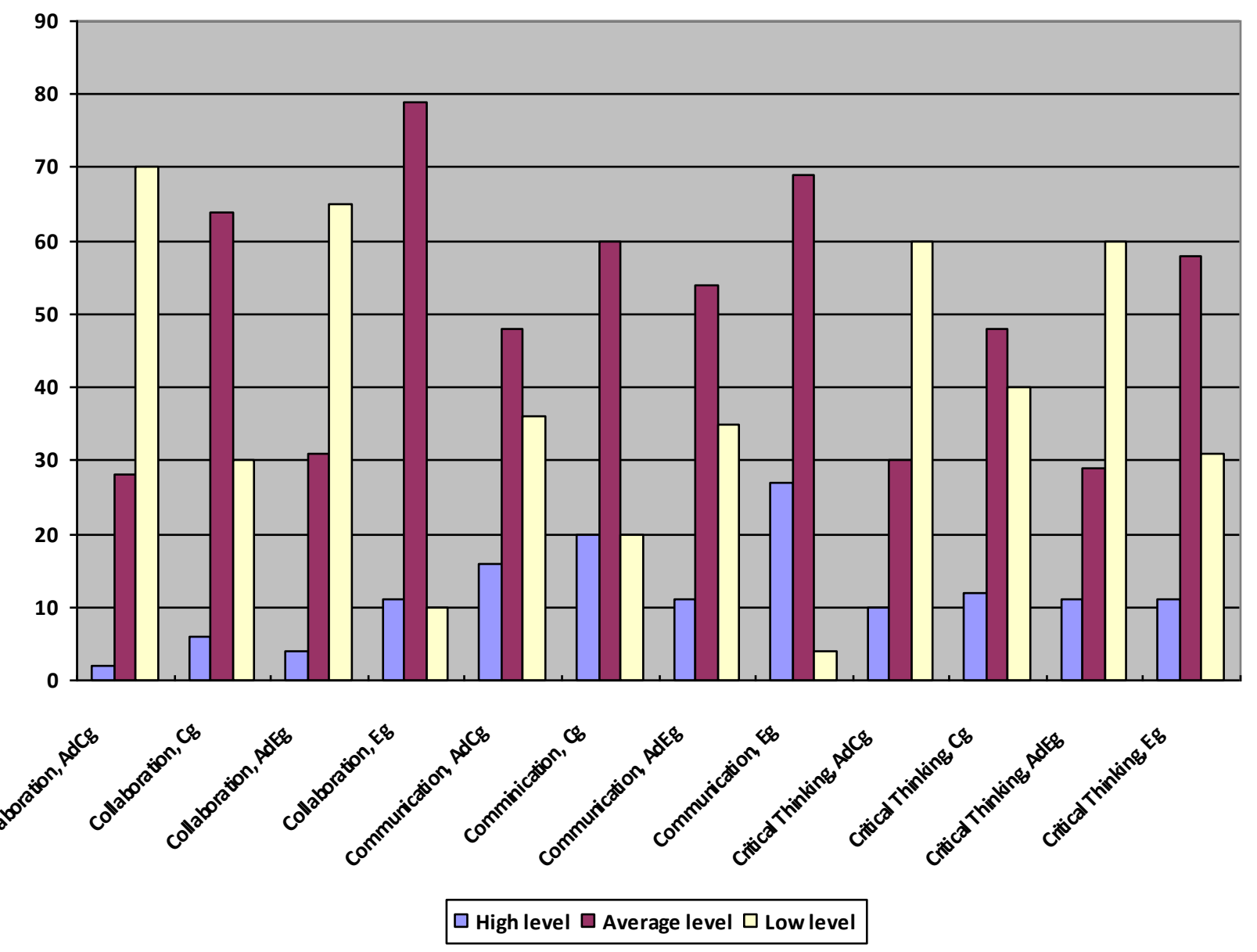

Figure 2: The dynamics of the soft skills being researched in the 2015-2016 experiment.

Note: Ad $\mathrm{Cg}$ - ascertaining diagnostics in the control group, $\mathrm{Cg}$ - final diagnostics in the control group, Ad Eg - ascertaining diagnostics in the experimental group, $\mathrm{Eg}$ - final diagnostics in the experimental group. 


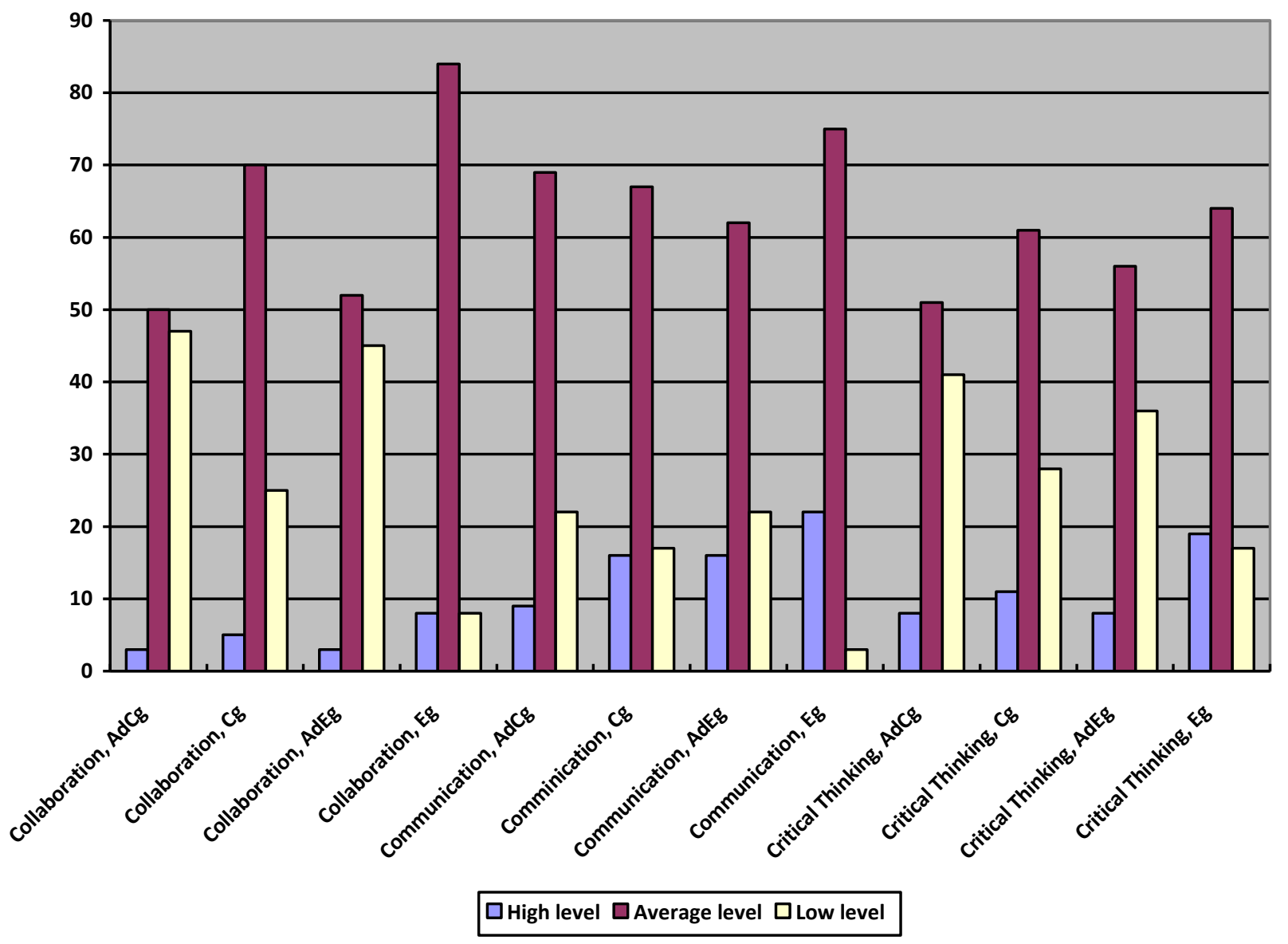

Figure 3: The dynamics of the soft skills being researched in the 2016-2017 experiment

Note: $\mathrm{Ad} \mathrm{Cg}$ - ascertaining diagnostics in the control group, $\mathrm{Cg}$ - final diagnostics in the control group, Ad Eg - ascertaining diagnostics in the experimental group, $\mathrm{Eg}$ - final diagnostics in the experimental group.

The obtained data were subjected to statistical analysis using Kolmogorov-Smirnov's test, Pearson's $\chi^{2}$ test and Spearman's rank correlation coefficient.

The comparison of quantitative date with standard normal distribution was carried out using Kolmogorov-Smirnov's test. The results of calculations are the empirical values of $\lambda_{\text {emp }}(0.54,0.55$, 0.37 , etc.). They are out of significance and differ from normal distribution.

The statistical significant differences of the data in the control and experimental groups after the experiment were therefore tested with the help of Pearson's $\chi^{2}$ test.

The results of the final diagnostics in the control groups indicate that:

1) the level of proficiency in teamwork and communication, in general, increased compared with the beginning of training, but not significantly. Probably, this is due to the fact that the ascertaining diagnostics was carried out at the beginning of the 1st semester, immediately after the formation of academic groups, when the students were not yet completely acquainted with each other, which of course made it difficult for them to communicate and work together. A slight increase in indicators is connected, perhaps, with the development of the ability to work with a partner at practical classes and with a certain experience of relationships over 2 semesters;

2) indicators of the formation of critical thinking skills only slightly increased (due to the fact that the ability to draw conclusions arising from factual material, judgments; to explain their 
reasoning is practically not required in the traditional approach to teaching a foreign language at the university, where tasks of the reproductive level generally prevail).

Probably, the data of the concluding experiment of the final diagnostics in the control groups can be interpreted as follows: the traditional approach to teaching a foreign language at the university leads to a more "average" level of formation of soft skills, but does not lead to their development.

The results of the final diagnostics in the experimental groups are as follows:

1) the growth of high and medium levels of skills;

2) the growth of indicators is higher at the second stage of the experiment than at the first. As for teamwork skills: the high level is increased by $3 \%$, the average level - by $5 \%$; communication skills of average level is 5\% more; critical thinking skills: high level - by $8 \%$, medium level - by 6\%. This can probably be explained, firstly, by an increase of classes and independent work time in the curricula in the 2016-2017 academic year; secondly, the teachers at the second stage have already had the experience of using role-playing games in order to develop the skills, being studied.

The dependence of the level of Collaboration skills on using academic role-playing games at classes of Foreign Language is statistically significant. The level of significance of this relationship $\left(\mathrm{p}=0.030-\right.$ at the $1^{\text {st }}$ stage, $\mathrm{p}=0.032$ - at the $2^{\text {nd }}$ stage of the experiment) corresponds to $\mathrm{p}<0.05$. $\chi^{2}=7.073\left(6.908-\right.$ at the $2^{\text {nd }}$ stage). The number of degrees of freedom are 2 . The critical value of $\chi^{2}$ $(\mathrm{p}=0.05)$ is 5.991. The number of degrees of freedom and critical value of $\chi^{2}$ are the same at all times.

The dependence of the level of Communication skills on using role-playing games is statistically significant too. The level of significance of this relationship ( $p=0.039$ at the $1^{\text {st }}$ stage, $p$ $=0.030$ at the $2^{\text {nd }}$ stage) corresponds to $\mathrm{p}<0.05 \cdot \chi^{2}=6.509\left(7.068-\right.$ at the $2^{\text {nd }}$ stage $)$.

The dependence of the level of Critical Thinking skills on using role-playing games is not statistically significant. The level of significance of this relationship $\left(\mathrm{p}=0.585\right.$ at the $1^{\text {st }}$ stage, $\mathrm{p}=$ $0.222-$ at the $2^{\text {nd }}$ stage $)$ corresponds to $p>0.05 . \chi^{2}=1.072\left(3.010\right.$ at the $2^{\text {nd }}$ stage $)$. However, the comparison of median values sheds more light on the matter.

The analysis of correlation between the skills was carried out using Spearman's rank correlation coefficient. The relationship between the levels of Collaboration skills and Communication skills (Collaboration and Critical Thinking, Communication and Critical Thinking) is always direct. The strength of relations on Chaddock's scale is high at all times. Spearman's coefficient of correlation $(\rho)$ is $0.780(0.782,0.856)$. Student's t-test is $8.823(8.869,11.729)$. The number of degrees of freedom (f) is always 50. The critical value of Student's t-test is 2.009. $t_{\text {exper }}>$ $t_{c r i t}$. This implies that the correlation between these skills is statistically significant $(p=0.000000)$.

\section{Discussion}

Most researchers refer to soft skills that can be divided into the following groups: social (adaptation, flexibility, sociability, ability to work with others, resolve conflicts, self-control; positive self-esteem); mental (problem solving, decision making, critical thinking, ability to work with information) and professional ones (goal setting, self-education, motivation, self-management and team-management) (Lippman, 2015; Dall'Amico \& Verona, 2015; Bika).

The set of soft skills that are formed and studied can vary in different educational systems. However, the basis, as noted by Griffin, the head of the Center for Evaluation at the University of Melbourne, is the so-called " $21 \mathrm{st}$ century skills" (they were defined in the framework of the Partnership for 21st Century Learning (P21) project and are used in the USA, Canada and New Zealand) which include skills of teamwork, communication, creativity, professional ethics and critical thinking (21st Century Skills Assessment). A large-scale study, the results of which were 
published in 2017, in which 123 experts from 45 countries (including European ones) participated, showed that the basic set of necessary soft skills has not changed in the last 5 years, at least, in technical education, but there is a connection between some preferred soft skills and the sociocultural situation in a particular country (Fernández-Sanz et al., 2017).

From the list of "the 21 st century skills" for this research we selected the following ones: teamwork skill, communication skill, and critical thinking skill.

An academic role-playing game was chosen as a means of forming soft skills in the process of mastering Foreign Language as an academic discipline.

The role-playing academic game as a means of forming soft skills is not such a topical issue in foreign studies. For example, Latif et al. (2018) found that role-playing academic games in the formation of critical thinking skills and communication skills are more effective than discussion. Taplin et al. (2018) proved that 10-minute role-playing academic games teach verbal communicative behavior in a foreign language in the workplace, the vision of conflict situations and their resolution. Role playing motivates, the games contribute to the formation of self-confidence and the formation of soft skills, which increases employment opportunities (Waters, 2016). Unfortunately, we have not found any domestic studies on the academic role-playing game as a means of forming soft skills.

In our case, the academic role-playing game is regarded as a methodical technique in which a student, assuming a certain role, can improvise in a given situation. The role-play learning function is determined by the choice of the language tools being trained, the development of speech skills and abilities, and the modeling of communication in various speech situations. In addition, participation in this kind of modeling requires students to be able to analyze the situation, to use the skills of a perspective view and their own experience and contributes to the development of social sensitivity (as the ability to understand and accept the opinion of another person). When solving specially-created practical training tasks in the game, it is possible to form the ability to find compromises, solutions, to accept changing conditions (which is typical for professional activities) and quickly adapt to them. The implementation of group tasks created by a teacher, for the devel opment of soft skills, involves mandatory interaction with group-mates and communication partners, which allows developing such skills as tactfulness and timeliness of reaction. Short-term (limited to an academic lesson) developmental projects that carry an atypical situation, allow the students themselves to assess the critical (unformed or insufficiently formed) soft skills.

\section{Conclusions}

The use of academic role-playing games, meaningfully aimed at forming soft skills of university students, majoring in non-philological subjects, at practical classes of Foreign Language (English) has proved its effectiveness in the course of the experiment. Using academic games on a constant basis contributes to the gradual development of the skills of teamwork, communication and critical thinking. The reliability of the results obtained is supported by an interdisciplinary approach to teaching Foreign Language, the integration and comparison of the results of pedagogical experiments as well as by the use of statistical analysis. As it was demonstrated, the relationship between the levels of Collaboration skills and Communication skills (Collaboration and Critical Thinking skills, Communication and Critical Thinking ones) is direct. The statistical strength of relations is high.

\section{References}

21st Century Skills Assessment. A Partnership for 21st Century Skills e-paper. Retrieved from https://ru.scribd.com/document/58428809/21st-Century-Skills-Assessment. 
Al-Araidah, O., Al Theeb, N., Bader, M. \& Mandahawi, N. (2018). A study of deficiencies in teamwork skills among Jordan caregivers. International Journal of Health Care Quality Assurance, 31 (4), 350-360. doi: 10.1108/IJHCQA-11-2016-0175.

Andrews, J., \& Higson, H. (2010). Graduate employability, 'soft skills' versus 'hard' business knowledge: A European study. Higher Education in Europe, 33 (4): Employability, Mobility and the Labour Market, 411-422. doi: 10.1080/03797720802522627.

Are They Really Ready to Work? Employers' Perspectives on the Basic Knowledge and Applied Skills of New Entrants to the 21st Century U.S. Workforce. Retrieved from https://files.eric.ed.gov/fulltext/ED519465.pdf.

Balcar, J., Simek, M. \& Filipová, L. (2018). Soft skills of Czech graduates. Review of Economic $\begin{array}{lllll}\text { Perspectives, } & 18 & \text { (1), } & \text { 45-60. } & \text { Retrieved }\end{array}$ https://www.researchgate.net/publication/323925663_Soft_Skills_of_Czech_Graduates.

Barseghian, T. (2011). Napa New Tech High: 5 Reasons this is the School of the Future. Retrieved from reas_b_805972.html.

Bartel, J. (2018). Teaching soft skills for employability. TESL Canada Journal, 35 (1), 78-92. doi: 10.18806/tesl.v35il.1285.

Best Practices in Soft Skills Assessment. (2014). Retrieved from https:/www.gssaweb.org/wpcontent/uploads/2015/04/Best-Practices-in-Soft-Skills-Assess ment-1.pdf

Bika, N. How to assess soft skills in an interview. Retrieved from https://resources.workable.com/tutorial/soft-skills-interview-questions.

Brooks, N.G., Greer, T.H. \& Morris, S.A. (2018). Information systems security job advertisement analysis: Skills review and implications for information systems curriculum. Journal of Education for Business, 93 (5), 213-221. doi: 10.1080/08832323.2018.1446893.

Callier, V., Singiser, R.H. \& Vanderford, N. (2014). Connecting undergraduate science education with the needs of today's graduates. F1000 Research, 3. doi: 10.12688/f1000research.5710.1. Retrieved from https://www.researchgate.net/publication/272080498_Connecting_undergraduate_science_e ducation_with_the_needs_of_today's_graduates.

Cambridge Dictionary. Retrieved from https://dictionary.cambridge.org/dictionary/english/softskills.

Chamorro-Premuzic, T., Arteche, A., Bremner, A.J., Greven, C. \& Furnham, A. (2010). Soft skills in higher education: importance and improvement ratings as a function of individual differences and academic performance. Educational Psychology, 30 (2), 221-241. doi: 10.1080/01443410903560278.

Chasidim, H., Almog, D. \& Mark, S. (2018). Fostering soft skills in project-oriented learning within an agile atmosphere. European Journal of Engineering Education, 43 (4), 638-650. doi: 10.1080/03043797.2017.1401595.

Chowdary, D.V. (2014). The importance of training engineering students in soft-skills. Abhinav. International Monthly Refereed Journal of Research In Management \& Technology, 3. Retrieved https://www.researchgate.net/publication/293313936_THE_IMPORTANCE_OF_TRAININ G_ENGINEERING_STUDENTS_IN_SOFT-SKILLS.

Cobb, E.J., Meixelsperger, J. \& Seitz, K.K. (2015). Beyond the classroom: fostering soft skills in Pre-Professional LIS Organizations. Journal of Library Administration, 55 (2), 1-7. doi: 10.1080/01930826.2014.995550.

Collins Dictionary. Retrieved 24/10/2018, from https://www.collinsd ic tionary.com/dic tionary/english/soft-skills 
Dall'Amico, E., \& Verona, S. (2015). Cross-country survey on soft skills mostly required by companies to medium/high skilled migrants. Methodological approach for a common framework of Soft Skills at work. Torino. Retrieved from https//conseil-rechercheinnovation.net/sites/default/files/public/articles/vhsm_determination_of_soft_skills.pdf.

Dalton-Puffer, Ch., \& Nikula, T. (2014). Content and language integrated learning. Language Learning Journal, 42 (2), 117-122. doi: 10.1080/09571736.2014.891370.

Devedzic, V., Tomić, B., Jovanovic, J., Sevarac, Z., Kelly, M., Milikic, N., Dimitrijevic, S. \& Djuric, D. (2018). Metrics for students' soft skills. Applied Measurement in Education, 31 (4), 283-296. doi: 10.1080/08957347.2018.1495212.

Diaz, V., Brown, M. \& Salmons, J. (2010). Unit 4: Assessment of Collaborative Learning Project Outcomes. Educause Learning Initiative. Retrieved from https://studylib.net/doc/18522428/assessment-of-collaborative-learning-project-outcomes.

Dorozyński, T., Świerkocki, J. \& Urbaniak, W. (2016). Employers expectations vis-à-vis graduates of faculties of economics. Results of a direct study. Comparative Economic Research, 19 (2), 93-109. doi: 10.1515/cer-2016-0015.

Espey, M. (2018). Enhancing critical thinking using team-based learning. Higher Education Research and Development, 37 (1), 15-29. doi: 10.1080/07294360.2017.1344196.

Fernández-Sanz, L., Villalba, M.T., Medina, J.A. \& Misra, S. (2017). A study on the key soft skills for successful participation of students in multinational engineering education. International Journal of Engineering Education, 33 (6), 2061-2070. Retrieved from https://www.researchgate.net/publication/321534626_A_Study_on_the_Key_Soft_Skills_for _Successful_Participation_of_Students_in_Multinational_Engineering_Education.

Fiore, S.M., Graesser, A., Greiff, S., Griffin, P., Gong, B., Kyllonen, P., Massey, Ch., O’Neil, H., Pellegrino, J., Rothman, R., Soulé, H. \& von Davier, A. (2017). Collaborative Problem Solving: Considerations for the National Assessment of Educational Progress. Retrieved from https://nces.ed.gov/nationsreportcard/pdf/researchcenter/collaborative_problem_solving.pdf.

Gaines, R.W., \& Mohammed, M.B. (2013). Soft Skills Development in K-12 Education. Research Brief. Retrieved from https:/2wh2pdomc1q415tdl40khdki-wpengine.netdna-ssl.com/wpcontent/uploads/2014/08/GLISI_SSResearchBrief_E1.pdf.

Gale, A.J., Duffey, M.A., Park-Gates, Sh. \& Peek, P.F. (2017). Soft Skills versus hard skills: practitioners' perspectives on interior design interns. Journal of Interior Design, 42 (4), 4563. doi: 10.1111/joid.12105.

Herzig, A., Lorini, E. \& Pearce, D. (2017). Social Intelligence. AI \& Society, 1. doi: 10.1007/s00146-017-0782-8

Hillmer, G. (2007). Social and Soft Skills Training Concept in Engineering Education. In: International Conference on Engineering Education - ICEE. Retrieved from https://docplayer.net/29565876-Social-and-soft-skills-training-concept-in-engineeringeducation.html.

Kaburise, Ph. (2016). Improving soft skills and communication in response to youth unemployment. International Journal of African Renaissance Studies - Multi-, Inter- and Transdisciplinarity, 11 (2), 87-101. doi: 10.1080/18186874.2016.1248061.

Kusumoto, Y. (2018). Enhancing critical thinking through active learning. Language Learning in Higher Education, 8 (1), 45-63. doi: 10.1515/cercles-2018-0003.

Laird, T.F., Shoup, R. \& Kuh, G.D. (2005). Deep learning and college outcomes: Do fields of study differ? $\quad$ Retrieved http://nsse.indiana.edu/pdf/conference_presentations/2005/air2005deeplearning-paper.pdf. 
Larmer, J., \& Mergendoller, J.R. (2010). The Main Course, Not Dessert. How Are Students Reaching 21st Century Goals? With 21st Century Project Based Learning. Retrieved from https://ru.scribd.com/document/109666630/The-Main-Course-Not-Dessert.

Latif, R., Mumtaz, S., Mumtaz, R. \& Hussain, A. (2018). A comparison of debate and role play in enhancing critical thinking and communication skills of medical students during problem based learning. Biochemistry and Molecular Biology Education, 46 (4), 336-342. doi: $10.1002 / \mathrm{bmb} .21124$.

Lippman, L.H., Ryberg, R., Carney, R. \& Moore, K.A. (2015). Child Trends: Workforce connections: key "soft skills" that foster youth workforce success: toward a consensus across fields. Retrieved from https:/www.childtrends.org/wp-content/uploads/2015/06/201524WFCSoftSkills1.pdf.

Mardis, M.A., Ma, J., Jones, F.R., Ambavarapu, C.R., Kelleher, H.M., Spears, L.I. \&, McClure, C.R. (2018). Assessing alignment between information technology educational opportunities, professional requirements, and industry demands. Education and Information Technologies, 23 (4), 1547-1584. doi: 10.1007/s10639-017-9678-y.

Mohamed, A.M., Abdullah, D. \& Dom, T.N.M. (2017). Soft skills of dental students' competence: What is important for patients and how do students fare? World Journal of Dentistry, 8 (3), 157-163. Retrieved

from https://www.researchgate.net/publication/317547473_Soft_Skills_of_Dental_Students'_Com petence_What_is_Important_for_Patients_and_How_do_Students_Fare.

OECD Skills Studies, Skills for Social Progress: The Power of Social and Emotional Skills. Retrieved from https:/www.oecd-ilibrary.org/education/skills-for-socialprogress_9789264226159-en.

Pang, E., Wong, M., Leung, C.H. \& Coombes, J. (2018). Competencies for fresh graduates' success at work: Perspectives of employers. Industry and Higher Education. doi: $10.1177 / 0950422218792333$.

Pezer, D. (2015). The Importance of Soft Skills in Technical Education. In: 7th International Scientific and Expert Conference of the International TEAM Society. Belgrade, Serbia, 7579. Retrieved from https://www.researchgate.net/publication/305360275_THE_IMPORTANCE_OF_SOFT_SK ILLS_IN_TECHNICAL_EDUCATION.

Ritter, B.A., Small, E.E., Mortimer, J.W. \& Doll, J.L. (2018). Designing management curriculum for workplace readiness: developing students' soft skills. Journal of Management Education, 42 (1), 80-103. doi: 10.1177\%2F1052562917703679.

Robles, M.M. (2012). Executive Perceptions of the Top 10 soft skills needed in today's workplace. Business Communication Quarterly, 75 (4), 453-465. doi: 10.1177\%2F1080569912460400.

Sisson, L.G., \& Adams, A.R. (2013). Essential hospitality management competencies: The importance of soft skills. Journal of Hospitality and Tourism Education, 25 (3), 131-145. doi: 10.1080/10963758.2013.826975.

Small Group Analysis. Retrieved from https://ru.scribd.com/document/138962090/Small-GroupAnalys is.

Tagg, J. (2003). The learning paradigm college. Bolton, MA: Anker Publishing Company. Retrieved from http://books.exfiles.ru/\#t=The+learning+paradigm+college+John+Tagg+;+foreword+by+Pet er+T.+Ewell.

Taplin, R., Singh, A., Kerr, R. \& Lee, A. (2018). The use of short role-plays for an ethics intervention in university auditing courses. Accounting Education, 27 (4), 383-402. doi: 10.1080/09639284.2018.1475244. 
Valentin, E., Hughes, C., Jose, R. \& Barreto, R. (2015). Rapid Improvement of Students' Soft-skills Based on an Agile-process Approach. In: 45th Annual Frontiers in Education Conference (FIE) El Paso, 2359-2367. doi: 10.1109/FIE.2015.7344408.

Vo, H.-Ph., Berglund, A. \& Daniels, M. (2017). A Perspective from Vietnamese Students on Teaching of Soft Skills. In: International Conference on Learning and Teaching in Computing and Engineering (LaTICE). Hong Kong, China. doi: 10.1109/LaTiCE.2017.11.

Vogler, J.S., Thompson, P., Davis, D.W., Mayfield, B.E., Finley, P.M. \& Yasseri, D. (2018). The hard work of soft skills: augmenting the project-based learning experience with interdisciplinary teamwork. Instructional Science, 46 (3), 457-488. doi: 10.1007/s11251017-9438-9.

Waters, B. (2016). "A part to play": The value of role-play simulation in undergraduate legal education. Law Teacher, 50 (2), 172-194. doi: 10.1080/03069400.2016.1162404.

Yan, L., Yinghong, Y., Lui, S.M.C., Whiteside, M. \& Tsey, K. (2018). Teaching "soft skills" to university students in China: the feasibility of an Australian approach. Educational Studies, 1-17. doi: 10.1080/03055698.2018.1446328.

Yehia, S., Gunn. C. (2018). Enriching the learning experience for civil engineering students through Learner-Centered Teaching. Journal of Professional Issues in Engineering Education and Practice, 144 (4). doi: 10.1061/(ASCE)EI.1943-5541.0000388. 